Ankara Üniversitesi Türk Inkllâp Tarihi Enstitüsü Atatürk Yolu Dergisi

S 51, Bahar 2013, s. 517-540

\title{
1950 Yılı Kars Milletvekilliği ve Belediye Seçimleri
}

\author{
Yrd. Doç. Dr. Cengiz ATLI*
}

Özet

Osmanll'dan Cumhuriyet'e geçiş sürecinde zor dönemler geçiren Kars'ın kaderi, 1923 'ten sonra değişmeye başlamış ve 1950'ye kadar Kars'ta, CHF/CHP etkin bir rol oynamıştır. 1946 yılında tüm illerde örgütlenme çalışmalarına başlayan DP'nin ise Kars'ta örgütlenmesi oldukça yavaş olmuştur. 1950'ye kadar Kars'ta yapılan diğer seçimlere katılamayan DP, 1950 seçimlerinde önemli bir başarı gösterememiş; bazı ilçelerinde güçlü olurken bazılarında ise istenilen başarıyı yakalayamamıştır. Bunda en büyük etken Kars'ın kendine özgü yapısı itibariyle DP'nin örgütlenememesi olmuştur. Halkı analiz ederek adaylarını belirleyen CHP ise Kars'ta kazanan parti olmuştur.

Anahtar Kelimeler: Kars, Seçim, Belediye, Milletvekili

\section{Kars' Deputy and Municipal Elections in 1950}

\begin{abstract}
Kars' fate, experiencing hardships during the transition period from Ottoman Empire to the Republican Era begins to change after 1923 and People's Republic Party $(\mathrm{CHP} / \mathrm{F})$ in Kars plays a major role until 1950. As for DP, which inititiates organizational efforts in 1946 in all the other cities, remains too slow in establishing its organizations in Kars. DP, which cannot join other elections held in Kars up to 1950, cannot obtain any noticeable achievement in 1950's elections. While DP proves to get the majority of the votes in several districts, it fails to have the desired result in the others. The most significant factor for this failure arises from the fact that DP cannot get organized because of the features peculiar to Kars. As for People's Republic Party (CHP/F), which determines its candidates by analyzing the public, wins the elections in Kars.
\end{abstract}

Key Words: Kars, Election, Municipality, Deputy, 1950

\footnotetext{
* Iğdır Üniversitesi Fen - Edebiyat Fakültesi Tarih Bölümü
} 


\section{Giriş}

23 Nisan 1920 'de toplanan TBMM'nin ilk yasama yılında işgal altında olan Kars'tan hiçbir milletvekili katılamadı. Kars'ın anavatana katılmasından sonra bu bölgede seçim yapılarak temsilcilerinin Ankara'ya gönderilmesi kararı alındı. Yapılan seçimlerin sonucunda Ali Rıza (Ataman) Bey, Fahrettin (Erdoğan) Bey ve XIII. Tümen Kumandanı Albay Mehmet Cavit (Erdel) Bey Kars Milletvekilliği'ne seçildi.

Cumhuriyetin ilanıyla bütün ülkede hayata geçirilen sosyo-kültürel ve ekonomik seferberlik kısa sürede Kars ve çevresinde de kendini hissettirmeye başladı. Cumhuriyet hükümetleri bölgede etkili olmak için bir takım adımlar atmakta gecikmedi. Bu yönde atılmış ilk adımlardan birisi Kars ve çevresinde CHF'nin örgütlenmesiydi. Bu maksada matuf çalışmalar kısa bir zaman içinde sonuçlandırılarak CHF örgütlenmesi tamamlandı. II. Dönem TBMM için yapılan seçim çalışmaları ve Halk Fırkası'nın kurulma sürecinin yurt genelinde yarattığı heyecanın en canlı yaşandığ birisi Kars ve çevresi oldu. Fırka Teşkilatı'nın kurulma çalışmaları Kars'tan büyük destek gördü, Eylül 1924 yılında da Teşkilat kurularak başkanlığına Bekir S1dk1 (Kubat)Bey getirildi.

1 Nisan 1923 tarihinde seçimlerin yenilenmesi kararının alınmasıyla 20 Nisan 1923'te milletvekili olmak isteyen adayların, beyannamelerini hazırlayarak Halk Fırkası'na başvurmaları istenmişti. Genel Merkeze gönderilen adayların başvuruları inceledikten sonra Kars'tan; Türkçülük fikrinin önemli isimlerinden biri olan bilinen Ahmet (Ağaoğlu) Bey ve Ticaret Odası Reisliği görevini yürüten Ömer Lütfi (Tarım) Bey aday olarak gösterildi ve II. Dönem TBMM Kars Milletvekili olarak seçildi.

Kars'da 1927 yılında yapılan milletvekili seçimlerin soncuna göre Ahmet (Ağaoğlu) Bey, Bedir (Firat) Bey, Mehmet Halit (Onaran) Bey, Baha Tali (Öngören) Bey, Sadrettin (Hattusas) Bey Kars Milletvekilliği'ne seçildi.

Çok partili siyasi hayata geçişin ikinci denemesi olan Serbest Cumhuriyet Fırkası'nın Kars şubesi, Eylül 1930'da Cihangiroğlu İbrahim Bey tarafından açıldı. Partiye halkın ilgisi umulanın üzerindeydi. 1931 yılında Milletvekili Genel Seçimleri yapıldı. CHF adayları seçimi kazandı. $\mathrm{Bu}$ dönemde milletvekilliği yapacak kişiler Ömer Kamil Bey (Ömer Lütfi (Küntay) Bey, Faik (Bermek) Bey, Mehmet Bahaettin Tali (Öngören) Bey, Mehmet Nazif (Sirel) Bey, Muhittin(Akyüz) Paşa idi.

Kültürel kurumlarla siyasetin birbirlerini yakından etkilediği bu günlerde yeni bir genel seçim ülke gündemine oturdu. Kars'ta da seçim 
hazırlıkları aralıksız devam etti. CHP seçime tek başına katıldı. Sorunsuz geçen 1935 Milletvekili Genel Seçimleri 'nin sonucunda Muhittin Akyüz, Yusuf Akçura, Baha Tali Öngören, Hüsrev Kızıldoğan, Esat Özoğuz, Ömer Kamil Kuntay, Mehmet Nazif Sirel halkın oylarıyla tekrar Kars Milletvekilliği'ne seçildiler. Diğer seçimlerde görüldüğü üzere Türkiye tarihinde önemli rol oynayan şahsiyetlerin bu seçimlerde de Kars'tan milletvekili olmaları dikkat çeken bir durumdu.

II. Dünya Savaşı yıllarında Türkiye'nin içinde bulunduğu zor şartlar birçok sorunu da beraberinde getirdi. Ekonomik darboğaz bütün şiddeti ile halkın yaşam alanını daraltırken uluslararası ilişkilerde yaşanan sorunlar da Türkiye'yi farklı mecralara sürükleyebilirdi. Bunlardan birisi de Kars'ın yanı başında bulunan Sovyet Rusya'nın toprak talepleri idi. Türkiye bu şartlar içerisinde VII. Dönem Türkiye Büyük Millet Meclisi'nde görev alacak milletvekillerini belirleyebilmek için 12 Ocak 1943 tarihinde seçimlerin yenilenmesine karar verildi. Bu seçim öncesinde CHP ilk defa illerdeki adayların sayısını arttırarak seçmene bunlardan birini tercih etme olanağı tanıd1. 28 Şubat 1943'te genel seçimler yapıldı. CHP adayları; Eşref Demirel, Cevat Dursunoğlu, Hasan Durudoğan, Şerafettin Karacan, Fuat Köprülü, Dr. Esat Oktay, Zihni Orhan, Esat Özoğuz Kars Milletvekilliği’ne seçildi.

7 Ocak 1946 tarihinde CHP'den ayrilan bazı Milletvekilleri Celal Bayar'ın önderliğinde birleşerek DP'yi kurdular. DP, 7 Ocak 1946 tarihinde tüm illerde örgütlenme çalışmalarına başladı. Her vilayetin kendine özgü şartları olmasından hareketle, Kars'ta DP'nin durumu ile ilgili olarak şu tespitlerde bulunabiliriz: DP'nin örgütlenmesi başlangıçta oldukça yavaştı. Sadece birkaç kazada bu yeni parti kendisine yaşam alanı bulabilecekti. Partinin üyeleri de CHP teşkilatlarından ayrılan kişilerdi. Bunların büyük bir kısmı da yönetimde yetki sahibi idi. Fakat ilerleyen süreçte DP, CHP ile şiddetli bir rekabete girdi. Doğal olarak burada sergilenen siyasi söylemin de yaşanılan tartışmalarda belirleyici rolü olacaktı. DP Genel Merkezi'nin CHP'ye yönelik eleştirileri Kars'ta da köylere kadar kendisini hissettirdi. Bunun karşısında CHP'nin takındığ 1 tavırda oldukça önemliydi. Bütün bu gelişmeler DP'nin örgütsel sorunları ile eş zamanlı olarak yaşandı. Çünkü DP'de çözülmeler başladı. Bu da DP'nin Kars özelindeki durumundan kaynaklanmaktaydı. Bazı ilçelerde güçlüyken, bazılarında ise istenilen ölçüde varlık gösteremedi. Yaşanılan siyasi rekabet toplumsal değer yargılarının sınırlarını zorlayacak seviyedeydi. Bu durumun halk nezdindeki yansıması ise DP'nin aleyhine olacaktı. 1950-1960 arası Kars'ta hiçbir varlık gösteremeyecekti. Bu genel değerlendirmeler 1şı̆̆ında DP Kars'ta yeterince örgütlenemediği için 1946 Milletvekili Genel Seçimleri'nden itibaren 
1950’ye kadar yapılan diğer seçimlere katılamadı. VIII. Dönem TBMM'de Kars'1 temsil edecek milletvekilleri ise Mehmet Bahadır, Akif İyidoğan, Aziz Semih İlter, Şerafettin Karacan, Esat Oktay, Zihni Orhon, Abdurrahman Sürmen, Tezer Taşkıran ve Hüsamettin Tugaç idi.

Tarihsel gelişim süreci içerisinde Kars'ta yaşanılan gelişmeler, günümüze de 1şık tutacak veriler içermektedir. Yapılan bu araştırmada elde edilen sonuçlar, Kars'ın öneminin geçmişte olduğu kadar günümüzde de devam ettiğinin bir işareti olarak değerlendirilmelidir. 21 Temmuz 1946 Milletvekili Genel Seçimleri'ne DP katılmamış ve seçimleri CHP büyük bir üstünlükle kazanmıştı. Bunda CHP'nin parti-devlet olma özelliği başta rol oynamıştı. DP'nin ülkede örgütlenmeye başlamasıyla taraflar arasında yaşanan rekabet büyük bir gerilime dönüşmeye başlamıştı. Halk bu iki kutuplu siyasetin arasında, gündelik yaşamına devam etmeye çalışıyordu. Kars'ta da diğer vilayetlerde yaşanılan sorunların benzerleri ile yüzleşilecekti. Yapılan olumsuz propagandaların etkisi ile toplumda ayrışmalara ve kamplaşmalara meydan verilmekteydi. Bilgi kirliliği had safhaya ulaşmıştı. Siyasi mücadele beraberinde manipülasyonları doğuruyordu. Bu durumdan hoşnut olmayan siyasiler buldukları ilk firsatta seslerini duyurmaya çalışmaktaydı. Bu şartlar içerisinde iki parti arasında da git-geller yaşanıyordu.

\section{1- 1950 KARS MÍLLETVEKİLİ SEÇIMLERİ}

\section{a)-CHP'nin Kars'ta Milletvekilleri Adaylarını Belirleme süreci ve CHP'nin aday adayları}

TBMM'de 14 Mayıs 1950 günü seçimlerin yenilenmesi kararlaştırıldı. Her seçim çevresinden çıkacak milletvekili sayısı 25 Mart 1950'de Bakanlar Kurulu kararıyla belirlendi. 1945 nüfus sayımı sonucu ve Milletvekili Seçim Kanunu'nun geçici 3. maddesi hükmüne göre alınan kararla Kars için 10 milletvekili seçilmesi kararlaştırıldı. ${ }^{1}$

Seçim tarihinin belirlenmesinden sonra partiler seçim hazırlıklarına başladı. CHP Genel Sekreterliği il başkanlıklarına bir yazı göndererek milletvekilliği adaylığı için il başkanlığına yapılacak müracaatların 8 Nisan 1950 günü saat 17.00 'ye kadar kabul edileceğini bildirdi. ${ }^{2}$ Başvurular, adaylar tarafından doldurulacak milletvekili başvuru formu ile yapıldı. ${ }^{3}$ Kars için öngörülen 10 milletvekilliği için 300 aday başvurusu alınacağ 1

\footnotetext{
${ }^{1} \mathrm{BCA}, 030.18 \cdot 1.2 .122 .27$

${ }^{2} \mathrm{BCA}, 030.01 .10 .54 .25$

${ }^{3} \mathrm{BCA}, 030.01 .51 .309 .4$
} 
duyuruldu. ${ }^{4} \mathrm{Bu}$ karar üzerine CHP il idare kurulu adaylık başvurularını kabul etmeye başladı. Kars milletvekilliği için başvuruda bulunan adaylar şunlardı:

Şerafettin Karacan:1892'de İstanbul'da doğdu. 1911'de Harbiye'den mezun oldu. Kurmay Subay olarak orduda görev aldı. Kurtuluş Savaşı'nda yaralandı. 1928'de Kurmay Binbaşı olarak Harp Akademisi'nde öğretmenlik yaparken emekli oldu. Ordudan ayrıldıktan sonra CHP'ye katıldı. Sirasıyla Kars, Samsun ve Antalya parti örgütlerinde çalıştı. Halkevlerinin denetlenmesi için oluşturulan heyetin içerisinde yer ald1. 1936'da valilerin parti başkanlığını üstlenmesi ile idari işlere ağırlık verdi. Nafia Vekâleti Münakalat İdaresi Başkanı, Posta Telefon ve Telgraf Umumi Müdürü olarak görev yapt1. 26 Mart 1939'da yedi yüz doksan bir oyla Kars Milletvekilliğine seçildi. 3 Kasım 1939'da meclise katıldı.

Abdurrahman Şeref Ergenekon:1902 yılında Kars Arpaçay'da doğdu. Erzurum Rüştiye mezunu olup İstanbul'da medrese eğitimi aldı. İstanbul Muallim Mektebi mezunu. İstanbul Üniversitesi Edebiyat Fakültesi Tarih Öğretmenliği Bölümünü bitirdi. Zonguldak Beycuma köyünde başöğretmen oldu. Milli Mücadelede yıllarında TBMM Hükümeti emrinde görev aldı. 1920-1921'de Bartın Lisesi Tarih-Coğrafya Öğretmenliği, 1922-1924'te Zonguldak İlköğretim Müfettişliği, İstanbul İmam-Hatip Mektebi TarihCoğrafya Öğretmenliği, Kars Vilayet Matbaası Müdürlüğü, Kars Gazetesi Mesul Müdürlüğü ve Başyazarlığı, Çanakkale Ortaokulu Tarih Öğretmenliği, Bursa Erkek Lisesi Tarih Öğretmeni olarak görev yaptı. Bakalorya Tarih Ders Kitabı, Anafarta Çanakkale, Cumhuriyetin 15. Yılında Halkevi Yayını, Köşeden İzler, Edebi Anadolu'da Gezi Notları kitapları yayınland1. ${ }^{5}$

Naim Ökden:1315 Buhara doğumlu. 1933-1935 İstanbul Üniversitesi Hukuk Fakültesi'nden mezun oldu. 1935-1938 yıllarında İktisat Vekâleti, Türk Ofis Teşkilatında ve Kars Bölgesi Türk Ofis Müdürü olarak görev yaptı. Aynı dönem içinde doğu vilayetlerinin iktisadı kalkınma alanında çalıştı.1937'de Kars'ta Canlı Hayvan İhracatçılar Birliği, Iğdır'da Pamuk Birliği ve Hayvan Borsalarında çalıştı. Bu çalışmalarını "Doğu İktisadi" adı altında bir raporla İktisat Vekâletine verdi. Diğer raporunda da Doğu Et Kombinasının kurulmasını teklif etti. Özellikle Samsun'da bulunduğu sırada bölgenin ekonomik kalkınmasını izledi. Bu bölgede ekonomik durum hakkında 1935 yılında Almanca eser yazdı.1939-1943 yılı Samsun Mintıka Ticaret Müdürü, 1943-1945 Samsun Mintıka Ticaret Azası, 1945-1948

\footnotetext{
${ }^{4}$ BCA, 490.01.10.53.13

${ }^{5} \mathrm{BCA}, 490.01 .306 .1242 .3$
} 
Ticaret Bakanlığı D1ş Ticaret Müşavirliği, 1948 y1lında itibaren İstanbul Belediyesi İktisat İşleri müdürlüğü görevlerinde bulundu. ${ }^{6}$

Selahattin Apaydın:1322 yılında İstanbul'da doğdu. Baba adı Hüseyin. İzmir Mıntıka Ziraat Mektebi mezunu. Diyarbakır merkezde ziraat öğretmeni görevlerinde bulundu. ${ }^{7}$

Zihni Orhan: 1883 yılında Erzurum'da doğdu. Babası Hacı Osman Efendi'ydi. İlk ve orta öğrenimini Erzurum Rüştiyesi'nde ve Askeri İdadisi'nde tamamladiktan sonra 13 Mart 1898'de Harbiye Mektebi'ne girdi. 2 Şubat 1901 'de Süvari Teğmen rütbesiyle mezun oldu. Çeşitli birliklerde takım ve bölük kumandanlığı görevlerinde bulundu. Rus hududunda görev yaptı. Burada arazi meseleleri ile ilgili olarak kurulan komisyonda çalıştı. 1 Eylül 1916'da rütbesi binbaş1llğa yükseltildi. III. Ordu emrine görevlendirildi. II. Kafkas Livası İdare Reisi Vekaleti'nde bulundu. 1 Ekim 1917'de merkezi Sivas'ta bulunan Asayiş Bölge Komutanlığı'na atandı. Kafkas Harekâtında Mürettip Süvari I. Alay Komutanı olarak 1878 Hududu'na ulaştı. Sedarabadda Ruslara ve Ermenilere karşı savaştı. Gence'yi aldıktan sonra Bakü Harekâtına katıldı. 26 Şubat 1919'da süvari Talimatnamesi'nde yapılacak değişiklik için kurulan komisyona memur edildi.18 Eylül 1919'da Erzurum XV. Kolordu emrine tayin edildi. Alayı ile Bayburt'un Hart Köyü'nde çıkan Şeyh Eşref Ayaklanması'nın bastırılmasında önemli görevler üstlendi. Son Osmanlı Mebusan Meclisi için 6 Ocak 1920'de yapılan seçimlere Erzurum'dan katıldı ve Erzurum Mebusu seçildi. Meclisin feshinden sonra Heyeti Temsiliye'nin talimatına uyarak Ankara'ya geldi. 23 Nisan 1920'de TBMM'nin açılışında hazır bulundu. Ancak görülen lüzum üzerine 9 Mayıs 1920'de Vekiller Heyeti kararıyla Sinop Mutasarrıf Komutanlığı'na atandı. 5 Eylül 1920'de kabul edilen Nisab-1 Müzakere Kanunu nedeniyle milletvekillik ile memurluğun bir kişi üzerinde bulunması yasaklandığından mutasarrıflığ 1 tercih etti. 4 Ocak 1922'de Bitlis Valiliği'ne nakledildi. 4 Ağustos 1923'de görevden alındı. 16 Eylül 1925'de kendi isteğiyle askerlikten emekli oldu. 1931-1935 yılları arası Kars'da CHP İ İdare Kurulu Başkanı olarak politika ile ilgisini sürdürdü. Zihni Orhon 26 Mart 1939'da yapılan seçimlerde 791 oyla Kars Milletvekilliği'ne seçildi. 26 Mart 1939 'da aldığı seçim mazbatasının 10 Nisan 1939'da genel merkezce onaylanması üzerine 3 Eylül 1939'da Meclis'e katıldi.

Abdurrahman Sürmen: Abdurrahman Sürmen 1907'de Sürmene'de doğdu. Eczacılık eğitimi aldı. Serbest eczacı olarak çalıştı.

\footnotetext{
${ }^{6} \mathrm{BCA}, 490.01 .306 .1242 .3$

${ }^{7} \mathrm{BCA}, 490.01 .306 .1242 .3$
} 
Mehmet Safi Molla Ceditoğlu:1918 Kars doğumlu. Baba adı Osman. Muhtarlık ve Ocak Merkez Kurulu üyeliği yapt1, Fen Memurluğu görevinde bulundu.

Abdullah Arpaçay:1324 Kars doğumlu. Ana adı Nergis, baba adı Ali. Mesleği gümrükçülük ve eşya eksperliği, tarım aletleri ihtisasıyla, hayvancılık idi. 17 yıl devlet memurluğu görevinde bulundu. İstanbul, Ankara, Edirne, Mardin, Kilis ve Zonguldak ilinin kazalarında Gümrük ve Tekel Bakanlığı'nda aza olarak görev yaptı. CHP'nin farklı kollarında çalıştı. ${ }^{8}$

İhsan Kurtalan: 1308 İstanbul doğumlu. Ana adı Ayşe Habibe, baba adı Salih.1328 Mekteb-i Mülkiye mezunuydu. II. Büyük Millet Meclisi seçiminde Halk Partisi adına çalıştı. Sarıkamış’ta Halk Partisini ve Türk Ocağı'nı kurdu. Son dönem Seydişehir ve Beyşehir'de çalıştı.

Emel Gürler: 1327 Trabzon doğumlu. Baba adı Hüseyin Hüsnü, ana adı Cavide. Korgeneral Şahap Gürler'in eşi. Burdur Lisesi mezunu. Burdur, Konya, Kars Halkevlerinde çeşitli görevlerde bulundu. Kars CHP İlçe Başkanlığı, Kars Yardımseverler kurucu ve başkanı, İstanbul CHP il propaganda kolu üyesi CHP Eminönü Kadınlar Kolu Başkanı, İstanbul Yardımseverler Merkez idare Kurulu üyesi ve veznedarı, İstanbul Kadınlar Birliği Heyeti İkinci Başkanı ve birinci başkanı oldu. Ayrıca Ankara Saraçoğlu CHP Ocağı Müteşebbis Heyeti Başkanlığı görevinde bulundu. ${ }^{10}$

Turgut Göle: 1329 Göle doğumlu. Baba adı Celal, Ana adı Feryal. Siyasal Bilgiler Okulu mezunu. Ankara Nahiye Memurluğu, Cebeci-Dikmen Nahiye Müdürlügü, Bala Kaymakam Vekili, Hafik-Çubuk Kaymakamlığı ve Gündoğdu kaymakamlığı görevlerinde bulundu. Üç sene Amerika'da staj yapt1. ${ }^{11}$

Hüseyin Altay:1385 Sürmene doğumlu. Baba adı Hasan, ana adı Hanife idi. İstanbul Erkek Lisesinden mezun oldu. Sarıkamış İlçesi Türkçe, Beden Eğitimi Öğretmenliği, Sarıkamış Ortaokulu Resim-Müzik Öğretmenliği, Iğdır Halkevi Spor Kolu Başkanlığı, Iğdır Halkevi Temsil Kolu Başkanlığı, Sarıkamış Halkevi Spor Kolu Başkanlığı ve Halkevi Başkanvekilliği, Sarıkamış Çocuk Esirgeme Kurumu Başkanlığı, C.H.P

\footnotetext{
${ }^{8}$ BCA, 490.01.306.1242.3

${ }^{9} \mathrm{BCA}, 490.01 .306 .1242 .3$

${ }^{10}$ BCA, 490.01.306.1242.3

${ }^{11} \mathrm{BCA}, 490.01 .306 .1242 .3$
} 
İstasyon Ocak Başkanlığı ve C.H.P İlçe İdare Kurulu Başkanlığı görevlerinde bulundu. ${ }^{12}$

Rasim Erdoğan:1330 Çıldır doğumlu. Baba adı Fazıl ana adı Elmas. Orman Fakültesi Mezunu. Yüksek Orman Mühendisi, Orman Genel Müdürlüğü Müfettişi olarak görev yaptt. ${ }^{13}$

Musa Kaya: Kağızman doğumlu CHP teşkilatının çeşitli kademelerinde çalıştı.

Feriz Yeşilkaya:1329 Kars doğumlu. Baba adı Şevket, ana adı Ziyaret. İçişleri Bucak Müdürü, 1930 Meslek Lisesi Öğretmen Muavinliği, 1934’ten sonra Digor Bucak Yöneticiliği görevini yürüttü. ${ }^{14}$

Hüseyin Talınlı: 1882'de Kars'da doğdu. Kars Halkevi Başkanlığı, Kars Belediye Başkanlığı ve Kars CHP İl İdare kurulunda çalıştı.

Ali Erdem:1326 Kağızman doğumlu. Baba adı İbrahim. Erzurum Öğretmen Okulu Mezunu. Kars'ın çeşitli ilçelerinde ve merkezde ilkokul öğretmenliği yaptı.1943-1945'te merkez Ortakapı Ocak başkanlığı yaptı. Son görevi Kars Merkez Gazi İlkokulu Başöğretmenliğiydi. ${ }^{15}$

Zarif Akman:1303 Sarıkamış doğumlu. Baba adı Sena, ana adı Sultan. Sarıkamış İlkokulu mezunu. Çiftçilikle uğraştı 1932 yılında Sarıkamış’ta ilçe idare kurulu üyeliği, 1934 yllında Genel Meclis üyeliği, 1942-1950 İl İdare Kurulu ve Genel Meclis üyeliği görevlerinde bulundu.

Aliyar Vural: 1893 yılında Çıldır'ın Purut Köyü'nde doğdu. Hacınebioğullarından Ali Eşref'in oğludur. 1920'de tarihinde işgal altında bulunan Çıldır'ın Milli mücadeleye iştirak eden Çıldır Gönüllü Alayı'na katılarak İstiklal Madalyası aldı. 1922'de Kars'da kurulan Müdafaa-i Hukuk Teşkilatı'nın içerisinde yer aldı. Sarıkamış örgütünü kurdu. CHP İdare Heyeti, Belediye, Türk Ocağ1, Ticaret Odası, İdman Yurdu gibi siyasi kurum ve derneklerde başkan ve üye sıfatıyla görev aldı

Rasim Illker: 1322 Ahıska doğumlu. Baba adı Haydar. Trabzon Öğretmen Okulu mezunu.1336 yılında Ahıska'yı terk ederek Anadolu'ya geldi. Öğretmen okulunu 1927'de Trabzon'da bitirdi. Aynı yıl Erzincan merkezde, 1928 ve 1929 yıllarında Ağrı il merkezinde, 1930 yılında Kars Sarıkamış Fevzi Paşa Okulunda başöğretmenlik yaptı. 1931-1932'de teğmen

\footnotetext{
${ }^{12}$ BCA, 490.01.306.1242.3

${ }^{13}$ BCA, 490.01.306.1242.3

${ }^{14} \mathrm{BCA}, 490.01 .306 .1242 .3$

${ }^{15}$ BCA, 490.01.306.1242.3

${ }^{16} \mathrm{BCA}, 490.01 .306 .1242 .3$
} 
rütbesiyle askerlik yaptı. 1932-1936 y1lları merkez Gazi Okulu başöğretmenliğinde bulundu.1936'da meslekten ayrıldı ve Ardahan ilçesinden genel meclis üyesi olarak seçildi. ${ }^{17}$

Rıfkiye Kağan:1326 Bursa doğumlu. Bursa Kız Muallim Okulu mezunu.1928-1935 yıllarında Kars merkez ve hudutta öğretmenlik yaptı. Türk kadınına siyasi hakların tanındığı 1935 yılında Göle ilçesi genel meclis üyeliği ve daimi encümen üyeliği görevlerinde bulundu. 1935 yılı CHP Kars ilçe başkanlığı ve İl İdare Kurulu üyeliğine seçildi. Partideki görevi halkın işlerini takip etmekti. Kars merkezde bulunan bütün cemiyet idari kurullarında ve altı yıl Yardımseverler Derneğinde başkanlık yaptı. ${ }^{18}$

Alaaddin Metan:1317 Ahıska doğumlu. Baba adı Seyfettin, ana adı Hacer. Ahıska Lisesi mezunu. Ticaretle uğraştı. 1336'da Milli Mücadeleye katıldı ve karargâhta Rusça baş tercümanı olarak çalıştı.1936-1945 yı1larında Ticaret Odası İdare Kurulu üyeliğinde II. başkanlık ve başkanvekilliğinde bulundu. Belediye meclis üyeliği, CHP merkez ilçe idare kurulu üyeliği ve Ticaret Borsası İdare Kurulu başkanlığında bulundu. ${ }^{19}$

Ali Yılmaz:1326 Posof doğumlu. Baba adı Tahir ana adı Miyeser. Posof İlkokulu mezunu. Ticaretle uğraştı. 1932-1945 yıllarında Posof Belediye Meclis üyeliğinde bulundu.1946-1947 yılında Posof CHP ilçe idare kurulu üyeliği, 1946-1950 İl Genel Meclis üyeliği ve İl Daimi Komisyon üyeliği görevlerinde bulundu. ${ }^{20}$

Fuat Hatungil:1328 Sivas doğumlu. Baba adı Nakiyettin ana adı Güneş. Teknik okul mezunu.1933-1938 Kars, 1938-1944 Sivas, 1944-1947 Tekirdağ Nafia Müdürlüğü görevlerinde bulundu. Müteahhitlikle uğraştı. ${ }^{21}$

Nadir Taşdemir:1312 Kars doğumlu. Baba adı Naki ana adı Sera. Ortaokul mezunu. Kars Bayındırlık Baş Makinisti.15 sene halkevi üyeliği yapt1. $^{22}$

Mustafa Öncül: Kağızman doğumlu öğretmenlik mesleğiyle uğraştı.

CHP'den aday olan ve isimleriyle birlikte özgeçmişleri de verilen bu 26 kişinin çoğunluğu yüksek eğitim almış, Milli Mücadeleye katılmış ve partinin çeşitli kademelerinde görev almış kişilerdi. Doğumu Kars olanların yanı sıra Kars dışından da başvuruda bulunanlar olmuştu. Ancak hepsinin bir

\footnotetext{
${ }^{17}$ BCA, 490.01.306.1242.3

${ }^{18}$ BCA, 490.01.306.1242.3

${ }^{19} \mathrm{BCA}, 490.01 .306 .1242 .3$

${ }^{20} \mathrm{BCA}, 490.01 .306 .1242 .3$

${ }^{21} \mathrm{BCA}, 490.01 .306 .1242 .3$

${ }^{22}$ BCA, 490.01.306.1242.3
} 
şekilde Kars'la yakın bir teması olmuştu. Adaylar içerisinde Karslı olanlar sayıca fazlaydı. İçerisinde kadın adaylarda bulunmaktaydı. Korgeneral Şahap Gürlerin eşi Emel Gürlerin partinin İstanbul teşkilatında yaptığ 1 çalışmalardan sonra Adaylık için Kars' 1 tercih etmesi ve öğretmen olarak görev yapan Rıfkiye Kağan bunlara örnek olarak gösterilebilir. Kars için bayan adayların olması olağan bir durumdu. Çünkü Mustafa Kemal Paşa'nın 1924 yılında Kars gezisinde eşi Latife hanımı getirmesi ve Türk Ocakları Genel Kongresinde eşi Latife Hanım'ı Kars delegesi olarak göstermesi bunun ilk işaretlerinden birisiydi.

\section{b)-C.H.P Kars İl Yoklama Kurulunun Toplanması, Milletvekili Adaylarının Belirlenmesi İçin Yapılan Seçim ve Sonuçları}

Adaylık müracaatlarının 8 Nisanda sona ermesinin ardından İl Yoklama Kurulu toplandi. CHP Kars milletvekili adaylarının \%80'ini belirleyecek $231^{23}$ kişilik Yoklama kurulu üyeleri CHP'nin Kars genelinde merkez ilçe ve

${ }^{23} \mathrm{Bu} 231$ kişinin isimleri şöyledir: İl İdare Kurulu Başkanı Saffet Tiryaki, İl İdare Kurulu Üyeleri; Genel Kurul Üyeleri Rasim İlker, Aliyar Vural, Zarif Akman, Veis Koçulu, üyeler: Necati Topçu, Osman Alp, Abdüllatif Aküzüm, Abbas Çetin, Rıfkiye Kağan ve Belediye Başkanı Tahir Barlas. C.H.P il idare kurulu yedek üyeleri: Şahin Yerdelen, Genel meclis üyeleri Hüseyin Talınlı, Zülfikar Durukan, Ticaret Odası Başkanı Bayram Erengiç, üyeler Celal Kazaklı, İbrahim Taşdemir, Hamit Temizel, Aslan Alp, Eşref Kaya, Kurultay Delegeleri: Musa Kaya, Mecit Yücel, Ahmet Koşucu, Mustafa Görceğiz, Genel Meclis Üyesi Ali Yılmaz, Ardahan C.H.P İlçe İdare Kurulu Üyesi Haşim Avşar, belediye Daimi Encümen üyeleri Muzaffer Demirbulak, Mehmet Kerimoğlu, Asaf Atbaş, Genel Meclis Üyeleri Kurban Yurtseven, Sarıkamış İlçe İdare Kurulu Kurultay Delegesi Hüseyin Altay, Üyeler Dursun Avc1, sabit Özkazanç, Hasan Köseoğlu, Hasan Demirci, Mehmet Gökalp, Aziz Tuncel, Hakkı Bildik, Hilmi Öğün, Sarıkamıș İlçesi Bucak Başkanları, selim Bucağı Hamza Tarhan, Karakut Bucağı Aziz Karakurt, Karaurgan Bucağı Seyfi Bildik, Sarıkamış genel meclis üyeleri Abbas Karakurt, Mustafa Bingöl, Memduh Çalkavur, Sarıkamış Belediye Başkanı Remzi Çakır, Sarıkamış Belediye Daimi Encümen Üyeleri Nafız Ocak, Rasim Tamburoğlu, Sarıkamış Halkevi Başkanı Gündüz Fumlu, Sarıkamıştan Kura ile İştirak eden Ocak Başkanları, İnönü Ocağı Zekeriya Kılıç, Bayram Çoban, Karakurt tan Mecit Karakurt, Karakale Pertev Aydın, Akçakale asker Bey, Kağızman Miktat Kaya, Hüseyin Günay. Hüseyin Toper, Akif Turan, Halis Tunç, Kazım Cücü, Esat Güneş Şahmettin Tunç, Ali Karadağ, Kağızman Kötek Bucağı Başkanı Muhittin Oktay, Kağızman Belediye Başkanı Ali Yüce, belediye Encümen üyeleri Mehmet Günay, Musa Cücü, Feyzullah Bilgi, Kağızman Halkevi Başkanı Fevzi Tugay, ve Kağızman'dan Kura İle İştirak eden Şahinlere Ocak Başkanı Ali Çelik, Kümbetler ocak Başkanı Halis Aras, Todan Ocak Başkanı İbrahim Bingöl, Kötek Ocak Başkanı Hasan Büyüktanır, Tillik Ocak Başkanı Mehmet Parlak, Çıldır C.H.P İlçe İdare Kurulu Üyesi Kurultay Delegesi Süleyman Vural, üyeler Aziz Aktemur, Rıza Çınar, Hüsrev Erdoğan, emir Oktay, Mehmet Şirin, Emin Gökçe, Kerem Soner, Yahya Kandemir, Çıldır Bucak Başkanı Ahmet Yılmaz, Osman Gödek, Çıldır Belediye Başkanı Atıf Ababay, Çıldır Belediye Daimi Encümen Üyeleri Rüstem Kılıç, Şahmurat Aydın, Çıldır Genel Meclis Üyesi Sümmani Akçay, Çıldırdan Kura İle iştirak Eden ocak Başkanları Ziya Karacan, Hakkı Şahin, Cabbar Özdemir, Ahmet Aktaş, Niyazi Altuntaş, Arpaçay C.H.P İlçe İdare Kurulu Ziya Özdemir, Necmettin Ilgar, Mikail Yılmaz, Durdağı erben, Kahraman Aktaş, Ramazan Aydın, Nebi 
bucak teşkilatlarından oluştu. Kars milletvekilliği için adaylık başvurusunda bulunan 26 kişiden 13'ünün ismi genel merkeze gönderilerek adaylık için

Aksoy, Veli Tanyıldız, İslam Göker, Arpaçay Bucak Başkanları; Kızılgökçek Ali Aydın, Başgedikler İhsan Yılmaz, Arpaçay Genel Meclis Üyeleri Mihrali Şengül, Hıdır Aksoy. Bayram Taştanoğlu, Arpaçay Belediye Başkanı Abdullah Avcı, Arpaçay’dan Kura İle iştirak eden ocak başkanları; Seydiköy Kazım Baykal, Uğurlu Enver Yıldırım, Polat Köyü Mecit Bulut, Keman Köyü Serdar Vural, Arpaçay Mahallesi İsmail Apaydın, Gök C.H.P ilçe İdare Kurulu Eyyüb Atalay, Zeki Bozkurt, Sabri Atalay, Gazi Taşdemir, Eyyüb Özentürk, Ömer Yani, Betül Kaftanoğlu, Şükrü Karakoç, Gök Belediye Başkanı Abdurrahman Bağrıyanık, Belediye Encümen Daimi Üyeleri Mustafa Özdemir, Kemal Bağrıyanık, Göle Genel Meclis Üyeleri Sürmeli Kaya, Mehmet Budak, Göle Akam Bucak Başkanı Bahri Ateş, Göle'den Kura İle İştirak Eden Verginiz Ocak Başkanı Ahmet Akın, Büyük Altınoluk Ocak Bașkanı Kemal Atalay, İlçe Merkez Ocak balkanı Mehmet Kılıç, Okan Merkez Ocak Başkanı Sıtkı Korkmaz ve Merkez Ocak Başkanı adil Bozkurt, Tuzluca C.H.P ilçe İdare Kurulundan Belediye daimi encümen Üyeleri Zekeriya Kırım, Hüseyin Boyder, Hüseyin Bayram, Settar Yenigün, Kahraman Gültekin. Yusuf Temuçin. Halkevi Başkanı Settar Savaş, Tuzluca genel Meclis Üyesi Ahmet Ayrım, Tuzluca Ticaret Odası Başkanı Ahmet Aytekin, Tuzluca Belediye Başkanı Abbas Temuçin, Tuzluca Bucak başkanları Tevfik Ayrım, Arif Kösebucağı, Ferah Akbal, Tuzluca'dan Kurayla iştirak eden Kamışlı Ocak Başkanı Kazım Akçay, Hadimi Ocak Başkanı Zafer Karalı, Ekerek Ocak Başkanı Hasan Atış, Gülüce Ocak Başkanı Osman Can, Türabı Ocak Başkanı Mecit Küçük, Ardahan C.H.P ilçe İdare Kurulundan Ticaret Odası Başkanı ve Kurultay Delegesi İsmail Baykal, Kaya Temur, Hafız Okyay, Meğrub Öktem, Haydar Mostra, Paşa Bozbey, Abbas Dündar, Belediye Başkanı Yusuf Güngör, Ardahan Genel Meclis Üyesi İlknur Turan, Ardahan Belediye daimi Encümen Üyeleri Sabri Özcan, Mikail Solmaz, Çiftçiler Birliği Başkanı Halit Kayatürk, Ardahan Hasköy Bucak Başkanı Sabri Avşar, Hanak Ocak Başkanı Nasrullah Öztürk, Yalnızçam Bucak Başkanı Nazım Özdemir, Kura ile Belirlenen Sarzop Ocak Başkanı İbrahim Karadağlı, Hasköy Ocak başkanı Kurban Yılmaz, Sindizkom Ocak Başkanı Reşit Doğruyol, Velköy Ocak Başkanı Ramiz Özcan, Köte malik Ocak Başkanı Binali Erdoğan. Posof C.H.P idare Kurulundan Alişar Ergün, Aslan Ergezer, İsmail Öztürk, Hacı Coşar, Avni Demirci, Dilaver Aktan, Mustafa Bulut, Rafet Özkaya, genel Meclis Üyesi Alaaddin Atalay Posof Genel Meclis Üyesi Ali Yılmaz, Posof Belediye Başkanı Mevlüt Dönmez, Belediye Daimi Encümen Üyeleri Rahmi Talar, Süleyman Demirci, Cilvene Bucağı Başkanı Ziya Yollaş, Merkez Bucak Başkanı Yusuf Doğruyol, Doğruyol Bucak Başkanı Kadir Çubuk, Aşköyü Ocak Başkanı Abbas Önalp, Samhulya Ocak Başkanı Nazım Özcan, Nuri Yılmaz, Lamya Ocak Başkanı Müjdat Topçu, Kalderdere Ocak Başkanı Ali Çamlıyurt, Iğdır C.H.P ilçe İdare Kurulu Hamit Çiftlik, Nefi Öcal, Belediye daimi encümen üyesi Hasan Çetinel, Bayer Sürmeli, İsa Yiğit, Sadık Tezel, Enver Güneş, Eşref Başaran, İslam Parlar, Belediye Daimi Encümen Üyesi Hüseyin Yayc1l, Ticaret Odası Başkanı Abdurrahman Güneş, Iğdır Belediye Başkanı Rıza Yalçın, Belediye daimi encümen Üyesi Edip Koçkaya, Başköy bucağı Başkanı Ali Yılmaz, Taşburun Ocak Başkanı Zeki Aksoy, Sefer Kulu, Söğütlü Mahallesi Ocak Başkanı Ali Bayat, Şileci Ocak Başkanı Hüseyin Akçay, Alican Ocak Başkanı Ziya Yanc1, Tazeköy Ocak Başkanı Mehmet Nayioğlu, Merkez İlçe İdare Kurulu Üyeleri İsmail Oktay, Nusret Metal, Ali Yeniaras, Mihrali Kaya, İskender Erkaya, Fahri Borluk, Hamza Karabağl1, İlyas Esmer, Haydar Akbaba, Merkez İlçe Bucak Başkanları Çakmak Bucak Başkanı Asker Koyuncu, Susuz Bucağ 1 Ocak Başkanı Duman Yaman, Hanzorik Ocak Başkanı Kasım Baransal, Çerme Ocak Başkanı Ali Tarhan, Harabe Taşnik Ocak Başkanı Şemsi Aynaş, Güdeli Ocak Başkanı Kanal İyneci, Karakale Ocak Başkanı Hamit Vergi BCA, 370.1561.2 
başvurularda bulunanları belirlemek için 9 Nisan 1950 günü seçim yapıldı. Seçimlerde Yoklama Kurulu üyesi olup da milletvekilliğine adaylığını koyanların toplantıyı terk etmesiyle seçimlere başlanarak Kars'tan seçilecek 10 milletvekilli için CHP adaylarından 7 sinin (\%70) tespit edileceği toplantıda seçimler yapıldı.

Seçimlerde CHP Bölge Müfettişi Urfa Milletvekili Atalay Akan Belediye Başkan Vekili, Belediye Başkanı Tahir Barlas, Kâtip; Sarıkamış Belediye Başkanı Remzi Çakır ve Iğdır Belediye Başkanı Rıza Yalçın görev yaptı. Seçim sonucunda sandık, kurul huzurunda açıldı zarflar tamamen çıkartıldı ve sandıkta zarf kalmadığı heyeti umumiyeye gösterildikten sonra sayılmaya başlandı. Tasnif Heyetinde Polat İmpolat, Settar Yenigün, Kazım Cücü, Mevlüt Dönmez ve İslam Gökyer yer aldı. Tasnif neticesinde; 140 oyla Tezer Taşkıran, 131 oyla Sırrı Atalay, 127 oyla Veis Koçulu, 116 oyla Latif Aküzüm, 111 oyla Esat Oktay ve 106 oyla Abbas Ali Çetin oy çokluğuyla yoklamayı kazandı. Diğer adaylardan Mehmet Bahadır 98, Fevzi Aktaş 79, Musa Kaya 78, Alaaddin Metan 55, Akif Eyidoğan 45, Zarif Akman 40, Rasim Erdoğan 37, Hüseyin Talınlı 36, Abdurrahman Sürmen 34, Hüsamettin Tugaç 26, Rasim İlker 19, Şerafettin Karacan 16, Hüseyin Altan 15, Rifkiye Kağan 11, Fevzi Yaşilkaya11, Şeref Ergenekon 9, Zihni Orhan 7 oy aldı. 2 oy ise başka isimlere çıktı. ${ }^{24}$

Birinci tasnif sonucunda tespit edilen 6 milletvekilinin salt çoğunlukla oy aldıkları görüldüğünden ikinci kez bir milletvekilliği adaylığı için tekrar seçime gidildi ve yapılan seçim sonucunda Mehmet Bahadır 122 oyla çoğunluğu kazand1. Diğer adaylardan Fevzi Aktaş 56, Musa Kaya 21, Alaaddin Metan'da bir oy aldı. Yapılan seçimlerin sonucu olarak CHP Kars milletvekilleri adayının 9'unu belirlemiş oldu. Kalan 1 aday da Genel Meclis tarafindan belirlendi.

1946 seçimlerinde Kars milletvekili olarak seçilenlerden Fevzi Aktaş, Mehmet Bahadır, Esat Oktay, Tezer Taşkıran ve Hüsamettin Tugaç tekrar aday gösterilmişlerdi. CHP Genel Merkezi ise dışarıdan seçimlere katılmadan Hüseyin Cahit Yalçın'ı aday gösterdi. CHP Kars'ta yapılan diğer seçimlere nazaran Seçim Kanunu'nu göz önünde bulundurarak 1950 Genel Seçimleri öncesi işi sıkı tuttu. Bundan önceki dönemlerde milletvekili adaylarını belirleme şeklinden, il örgütü ve partiye gönül vermiş olanlarda rahatsızlık ortaya çıktığı için halk nezdinde partiyi daha güçlü kılmak ve daha nitelikli adaylarla seçime girmeyi düşünmüşlerdi. Seçim sonuçlarına göre CHP tarafından 8. Dönem Milletvekili Fevzi Aktaş, Avukat Latif Aküzüm, Yargıç Sırrı Atalay, 8. Dönem Milletvekili Mehmet Bahadır,

\footnotetext{
${ }^{24}$ BCA, 490.01.306.1242.3
} 
Avukat Abbas Çetin, Tüccar Veis Koçulu, 8. Dönem Milletvekili Esat Oktay, Tezer Taşkıran, Hüsamettin Tugaç ve Hüseyin Cahit Yalçın aday gösterildi. ${ }^{25}$

c)-CHP Kars Milletvekili Adaylarına Yönelik Tepkiler, Milletvekilleri Aday Listelerinin Belirlenmesinden Sonra Kars'ta Yaşanan Tartışmalar

Kars ilinde adayların belli olmasından sonra CHP İl İdare Kurulu Başkanı adayların belirlenmesinden duyduğu rahatsızlığı içeren bir raporunu CHP Genel Sekreteri Konya Milletvekili Fikret Sıla'ya gönderdi. Raporunda, aday yoklamasının Divan Azas1 Esat Oktay tarafindan hazırlamış olan grubun kazandığını belirterek yoklama sonucunda çeşitli dedikoduların yapılmaya başlamasından bahsetti. Halk arasındaki konuşmalara göre oylar para ile alınmıştı. Bu sebepten dolayı halkın \%80'i para ile milletvekili adaylığını kazanmış olan bu adaylara oy vermeyeceklerini, bunlara vermeyerek DP adaylarına oylarını vereceklerini söylemişlerdi. Bu olaydan dolayı birçok partilinin istifa ettiğini belirtilerek, partinin adaylarının kazanması ve halk tarafından çok sevilen partililerin istifadan döndürülmesi için gerekli çalışmanın yapılması istendi. ${ }^{26}$

Kars İlinde Kars Bölge Müfettişi Urfa milletvekili Atalay Akan da Genel Sekreterliğe gönderdiği raporda CHP ve DP adaylarını değerlendirdi. $\mathrm{Bu}$ raporda "DP Kars Vilayeti'nde ciddi olarak çalışmaktadır. Başkanları Avukat İsmail Alaca, Göleli çiftçi Ahmet Kağan ve Tüccar Zeki Aras seçim kabiliyetleri kuvvetli insanlardır. İyi bir aday listesini çıkarmaya çalıştıklarını ve bizim yoklamada çıkacağını umduğu anlaşmazlıklardan faydalanmaya çalışacakları anlaşılmaktadır. CHP İl İdare Kurulu birbirine sayg1 ve sevgi gösteriyor iseler de gerçekte birbiriyle çatışan gruplar halindedir. Gruplaşma milletvekili ara seçimlerinde meydana gelerek il ilçe kongrelerinde genel meclis ve daimi encümen seçimlerinde tesirini yaptı. Asıl üzüntülü noktada bütün halkı birbirinden ayıran Azerilik, yerlilik, Karadenizlilik gibi menşee ve Sünnilik-Şiilik ${ }^{27}$ gibi mezhep farklarının

\footnotetext{
${ }^{25}$ Kars Gazetesi, 26 Nisan 1950, S.1824

${ }^{26} \mathrm{BCA}, 490.01 .306 .1242 .3$

${ }^{27} 1921$ itibariyle Kars ve çevresini terk eden Ermeniler, Rusya’ya yerleştiler. Böylece bu bölgeyi boşalttılar. Rusların ve Ermenilerin bu bölgeyi terk etmesinden sonra buraların sahipsiz kalmasını önlemek amacıyla boş olan yerlere Azerbaycan'dan Kars'a yerleşen Azeri Türkleri, Bolşevik cereyanının Kafkasya'da yayılması sırasında bu rejime karşı olan Karapapak Türkleri, dar arazili ve geçim sıkıntısı içinde yaşayan Karadenizliler ve Anadolu'nun çeşitli yerlerinden göçüp yerleşen Türkler yerleştirildi. Bu göçler, Kars'ta bir takım problemler yarattı. Yerli halk ile göçmen Türkler arasında ticari anlamda var olan rekabet ileriki yıllarda Şii-Sünni ayrılığına döndü. Bu etkiyi ve ayrımcılığı ortadan kaldırmak
} 
ortaya atılarak faydalanmak istenmesidir. Seçimler üzerinde muhtemel kötü tesirleri önlemek için her şeyden evvel ilk idare kurulundaki arkadaşları birleştirmeye çalışmaktayım. Ancak bu arkadaşlardan 9'u adaylıklarını koymak istedikleri için kurul dışındaki adaylar ve mevcut milletvekillerinden karma listeler tertiplenerek muhtelif propagandalar yapılıyor. İlçenin bu çalışmalara katıldığ 1 haberleri alınıyor”. Bu raporunda seçim sonuçlarının ne olacağına dair tahmininde ise "mevcut milletvekillerinin seçim kabiliyetleri genellikle yeni adaylardan daha kuvvetlidir. Bununla beraber seçimlerin sonucunu kestirmek zordur", diyerek 1950 seçiminde DP'nin de iddialı olduğunu dile getirdi. ${ }^{28}$

Şikâyet dilekçelerinin biri de Veis Koçulu'nın CHP tarafından aday gösterilmesini engellemek için Karslı Mehmet Koçulu tarafından CHP genel sekreterliğini gönderilen dilekçedir. Dilekçede "Veis Koçulu partinin verdiği paralarla seçildi. Seçim Kanununun 34. Maddesinin 4. bendinde bildirildiği gibi (yabanc1 devlet hizmetinde bulunanların) milletvekili olamayacağ 1 bildirildi. Fakat Veis Bey Sovyet Rusya subaylarındandır, aynı zamanda Rus Emniyetinde çalıştı. ve hükümetin sürgünleri arasında iken para ile Kars'ın Mezra Köyünde Fukara Veis ismindeki bir adam onun yerine sürgüne gönderildi. Ayrıca Veis Bey 1937 senesinde fakir bir köylü iken nasıl bu kadar zengin bir hale geldi", diyerek Veis Koçulu'nun aday gösterilmesi halinde CHP Kars teşkilatını zarar göreceğini belirtti.

\section{d)-DP'nin Milletvekili Adayları}

DP Kars teşkilatı yaptığı il içindeki yoklama sonuçlarına göre adayları belirledi. Adaylar çoğunlukla Kars İlinde ikamet edip yüksek mevkilerde çalışanlardan seçildi ${ }^{29}$. DP'nin Kars'taki adayları şu isimlerden oluşmaktaydı:

-İsmail Alaca: DP İl Başkanı. Kars doğumlu, avukat, Kars’ta ikamet ediyor.

-Nevruz Gündoğdu: Çıldır doğumlu, öğretmen, tüccarlıkla uğraşıyor, Kars'ta ikamet ediyor.

amacıyla Kars'ta yaşayan bütün halk üzerinde; Türkçülük fikri etrafında Rus etkisini silmek ve inkılâpların bölgede daha iyi benimsenmesini sağlamak için çalışmalar yapıldı. Bu çalışmalar içerisinde Türkçülük fikirlerinin önde gelen isimleri Kars Milletvekili olarak görev yapt1 BCA, 490.01.837.306.2.

${ }^{28}$ BCA, 490.01.306.1242.3

${ }^{29}$ Kars Demokrat Parti Teşkilatı 1946 yılında kurulmaya çalışıldı fakat oluşumunu tamamlayamadığı için 1946 seçimlerine katılamadı. Sadece üç yerde kuruluşunu tamamlamaya çalıştı. Merkez Parti başkanlığını Avukat İsmail Alaca, Göle İlçe Başkanlığını Ahmet Kağan ve Sarıkamış İlçe Başkanlığını Fahri Yaman yürüttü. BCA, 490.01.306.1242.3 
-Zeki Aras: Kağızman doğumlu. Tüccar, Kağızman'da ikamet ediyor. Başkanı.

-Ahmet Kağan: Göle doğumlu, çiftçi, Göle'de oturuyor. DP Göle İlçe

-Ali Topçu: Sarıkamış doğumlu, orman mühendisi.

-Kemal Tuğcu: Sarıkamış doğumlu, Doktor, Ankara'da ikamet ediyor.

-Fazıl Baykal: Iğdır doğumlu, tüccar, Iğdır'da ikamet ediyor.

-Fahri Yaman: Sarıkamıș doğumlu, dava vekili, Sarıkamıș'ta ikamet ediyor. Sarıkamış ilçe DP Başkanı ${ }^{30}$

-Emin Akınc1: Emekli Kurmay Albay.

-Turgut Babaoğlu: Serbest hekim, operatör. ${ }^{31}$

e)-Bağımsız Adaylar:

DP ve CHP dışında Kars'tan bağımsız adaylar da başvuruda bulunmuşlardı. Bağımsız aday olarak başvuran isimler ise şunlardı:

-Ali Riza Ataman: I. Dönem TBMM Kars milletvekili.

-Neşat Akmanlar: Emekli Korgeneral.

-İbrahim Alter: Emekli Binbaş1.

-Mehmet Budak: Göle Genel Meclis üyesi. Seçimlere bağımsız olarak katılan Mehmet Budak CHP'den aday adayı olarak başvurdu. Aday gösterilmemesi üzerine bağımsız olarak adaylığını koydu. CHP'de bu tavrından dolayı partiyle ilişkisini kesti. ${ }^{32}$

-Ali Erdem: Gazi İlköğretim Başöğretmeni.

-Mustafa Tombul: Malatya Sulh Yargicı. ${ }^{33}$

\section{f)-CHP ve DP'nin Seçim Çalışmaları}

CHP 14 Mayıs 1950'de yapılacak olan seçimlerde takip edeceği yöntem konusunda Ankara'dan gelecek talimatlara göre hareket edecekti. CHP Parti Teşkilatının, seçim kampanyasını İsmet Paşa üzerinden yaparak halkı tesir altında bulundurmak istedi. İsmet Paşa 1950 yılında verdiği demeçte "Bütün vatandaşlarımızın bilmesini isterim ki CHP seçimde çokluğu kaybederse,

\footnotetext{
${ }^{30}$ BCA, 490.01.306.1242.3, Kars Gazetesi, 26 Nisan 1950, S.1824

${ }^{31}$ Zafer Gazetesi, 25 Nisan 1950; Erol Tuncer, 1950 Seçimleri, Ankara, 2010, s. 83.

${ }^{32}$ BCA, 490.01.306.1242.3

${ }^{33}$ Kars Gazetesi, 26 Nisan 1950, S.1824
} 
İsmet İnönü tabiatıyla ve elbette Cumhurbaşkanlığından çekilecektir"34, diyordu.

İsmet Paşa'nın 1950 seçimlerinin kazanılacağı konusunda bazı endişeleri vardı. Seçimler öncesinde iktidarla işçilerin yaşadığı sorun, köylülerin iktidarın politikalarından memnun olmayışı İsmet Paşa'nın bu endişesini artırmaktaydı. İsmet Paşa dışında CHP teşkilatının tamamı seçimlerin kazanılacağından emindi. ${ }^{35}$ Seçim çalışmalarının başlamasıyla tüm yurtta propaganda faaliyetleri hız kazandı. İsmet Paşa ve CHP'nin önde gelen isimleri yurt gezileri ve mitingler yapmaya başladı. İllerde ise İl İdare Kurulları yoğun propaganda faaliyetine girişti.

Kars'ta ise yoklama kurulu yapılmadan önce çok yoğun yapılan çalışmalar milletvekili adaylarının belli olmasıyla hızlandı ${ }^{36}$. Seçimlerden önce CHP Kars Bölge Müfettişi Urfa milletvekili Atalay Aka'nın Kars'a yaptığı teftiş gezisi sonrası Genel Sekreterliğe sunduğu raporda teşkilatın çalışmaları hakkında şu bilgileri vermekteydi: "Iğdır, Tuzluca ilçelerinde durum lehimize. Kağızman ilçesinde ise bir taraftan Musa Kaya'nın aday olmaması yüzünden küskünlükleri diğer taraftan serbest aday Ali Rıza Ataman'ın Kağızmanlı olması dolayısıyla parti faaliyetleri azdır. Adaylar uygun görülen alanlara dağıtıldı. İşin garip tarafı birbirine itimat etmeyen adaylar birer ikişer kendilerinin kazanmaları lehine çalışmak istedikleri, işleri güçleştirmektedir. Kars Belediye Başkanı Tahir Barlas ve İl İdare Kurulu Başkanı Saffet Tiryaki çok ciddi çalışmaktadır. Validen yardım görüyoruz. Ardahan'a gönderilen Tezer Taşkıran ve Mehmet Bahadır Posof'la meşgul olacaklardır. Abbas Çetin Iğdır'da, Latif Aküzüm Tuzluca'da, Dr. Esat Oktay ve bir daimi encümen üyesi Çıldır'da, Sırrı Atalay Kağızman'da, Fevzi Aktaş Arpaçay'da görevlendirildi. Veis Koçulu yardımcı olarak istenilen yerlere gönderilmektedir. Merkez ilçe Sarıkamış ve Göle teşkilatı arkadaşlarıyla birlikte bizzat ben meşgul olacağım.”

Atalay Akan raporunda çalışmaların neticelerini de şöyle anlatmıştır: "Kars'ın anlattığım hususiyetlerini ve iki ilçeniz hariç parti teşkilatını zayıflık veya normalliğini ve adayların durumunu gözden tutmayarak gece gündüz çalışıyoruz. Bu gün durum partimizin lehinedir. Faaliyetimiz her tarafta günden güne artmaktadır. Adaylarımız kendilerine 1srarla tavsiye ettiğim şekilde birbirlerine itimat ederek çalışırlarsa listenizin kazanma şansı

\footnotetext{
${ }^{34}$ Rıfkı Salim Burçak, On Yılın Anıları, (1950-1960), Ankara, 1998, s.42.

${ }^{35}$ Faik Ahmet Barutçu, Siyasi Anılar (1939-1954), İstanbul, 1977, s.414-415

${ }^{36}$ Kars Gazetesi 5 Nisan 1950, S.1818
} 
muhaliflerden fazladır ${ }^{\prime 37}$, diyerek seçimlerde kazanma şanslarının yüksek olduğunu açıklamıştır.

CHP seçim çalışmaları için illerde propaganda ve konuşma faaliyetlerine başladı.24 Nisan 1950 günü Iğdır'da ilk açık hava toplantısı yapıldı. Hüseyin Cahit dışındaki tüm CHP adayları, il başkanları, yönetim kurulundan birkaç üye, parti müfettişi ve Urfa Müfettişi Atalay Akın Iğdır'a geldi. Toplantıdan bir gün önce DP Iğdır'da toplantı düzenleyerek CHP iktidarını şiddetli biçimde eleştirdi. CHP milletvekilleri de düzenlenen toplantıda söz alarak DP'ye yanıt vermişlerdi. CHP'nin hizmetlerini ve seçimlerin önemini belirten konuşmalar yapıldı.

CHP 26 Nisan 1950'de Sarıkamış’ta bir toplantı düzenledi. Toplantıda ilk konuşmayı yapan ilçe başkanından sonra Tezer Taşkıran ve Hüsamettin Tugaç da birer konuşma yaptı. Daha sonra diğer partililer konuşma yaparak CHP'nin seçim stratejisini anlattı. Fakat Sırrı Atalay'ın toplantıda yaptığ 1 konuşma sorgulanma konusu oldu. Kendisi sorgulanmak üzere toplantıya çağırıldı. Toplantıda DP'yi övdüğü, CHP'nin iktidar yorgunluğu içinde tarihi görevinin bulunduğu, ailesinin CHP'li olduğunu ama kendisinin yaptığ konuşmayla DP li gibi davrandığını iddia edildi, bu konuşmadan ötürü partiyi güç duruma düşürdüğü ve hakkında önlem alınması gerektiği öne sürüldü.

Sırrı Atalay, Saffet Tiryaki'nin katıldığı savunma toplantısında söz alarak Sarıkamış konuşmasıyla demokrasiyi savunduğunu, önümüzdeki 14 Mayıs seçimleriyle Türkiye'nin dürüst bir seçimle dünyanın gözü önünde dürüst bir sınav vereceğini, çok partili hayatın doğal sonucu olarak bir iktidar değişikliği olabileceğini, DP'nin iktidara gelmesiyle sanıldığı gibi kıyamet kopmayacağ 1 , bu durumda CHP'nin iktidar yorgunluğundan kurtulup yeniden güç kazanacağını açıkladı. Sırrı Bey Partinin seçim sonuçlarına hazırlıklı olarak Asya kıtasında Japonya'dan sonra ilk kez Türkiye'de iktidarın halkın iradesiyle değiştirilmesinin ülkeye büyük güç katacağını, 1946 seçimlerinin ağır suçlamalarından ülkenin ve partinin kurtulacağını anlattı. ${ }^{38}$

\section{ğ)-1950 Milletvekilliği Seçimleri ve Kars Milletvekilliği Seçimleri}

1950 seçimlerine gidiş sürecinde muhalefet iktidar çelişkisi açmazlara girme yolundaydi. Toplumsal muhalefetten güç alan parlamenter muhalefetin demokrasisi yolunda isteklerine karşı koyma gücü

\footnotetext{
${ }^{37} \mathrm{BCA}, 490.01 .306 .1342 .3$

38 Sırrı Atalay, Bir Ömür Politika, Kars'tan Zincirbozan'a, Milliyet Yayınları İstanbul 1986, s.88-89
} 
kalmadığından CHP'nin tek parti döneminin getirdiği alışkanlıklar ve ilkeleri teker teker bırakmaya bunun da ötesinde muhalefetle iyi geçinmek adına bir takım tavizler verip DP'nin muhalefet çizgisinin bizzat düşünceleri doğrultusunda bazı kararlar almaya başladığı görüldü. ${ }^{39}$

1946 seçimlerinden sonra DP, bütün çabasını yeni bir seçim kanunu çıkarmaya harcadı. DP'ye göre serbest ve dürüst seçimlerin yapılmasını temin edecek bir seçim sisteminin kurulması, demokrasinin gelişmesi için şarttı. ${ }^{40}$ İktidar ve muhalefet arasında seçim sistemi konusundaki görüş ayrılığ 1948 yılının ortalarına doğru boşalan milletvekillerinin bir ara seçim ile doldurulması söz konusu olduğunda ortaya çıktı. Muhalefet ve basın halkın desteğiyle 21 Temmuz seçimlerini "Kötü ve antidemokratik" bir olay olarak ilan etmesiyle meydana gelen olaylar sonucunda 1948 ara seçimlerinden sonra iktidara gelen Günaltay Hükümeti yeni bir seçim kanunu hazırlama zorunluluğu duydu. ${ }^{41} \mathrm{Bu}$ amaçla Kanun 16 Şubat 1950 tarihinde 5545 sayılı yasayla kabul edildi. Kanunun çıkarılmasındaki temel amaç seçimlerin serbestliğini ve dürüstlügünün sağlama konusunun ön planda tutulduğu, gizli oy açık sayım ilkesinin ve yargıç denetimini gerçekleştirecek bir kanunun hazırlanması olmuştu.

$\mathrm{Bu}$ yasaya göre milletvekili seçimi tek dereceliydi ve çoğunluk yöntemine göre genel, eşit, gizli oyla yapılırdı. Oy serbest ve kişiseldi. Oyların sayılması ve ayrılması açıktı. İktidarla muhalefet arasındaki anlaşmayı yansıtan bir seçim yasasının varlığı 1950 seçimlerine Türk seçim tarihinin demokratik, yarışmacı ve dürüst yapılan ilk seçim olma özelliğini kazandırmıştı.

$\mathrm{Bu}$ kanun doğrultusunda yapılan 14 Mayıs 1950 seçimlerine oldukça büyük bir katılım oldu ve geçerli oyların büyük bir çoğunluğunu DP alarak mecliste temsil gücü sağladı. Bu seçimlerde Türkiye'de halk ilk defa olarak serbest irade ve oy yoluyla iktidarı değiştirerek, kendi yöneticilerini seçti. Böylece tek parti sisteminden çok partili sisteme geçiş süreci tamamlanmış, iktidar barışçı bir şekilde el değiştirmişti. "Kansız İhtilal" ya da "Genel Oy Devrimi" diye adlandırılan bu büyük dönüşümle Tek Parti Dönemi sona erdi. $^{42}$ Daha esnek bir laiklik anlayışı, yol, su gazyağı, şeker, ucuz yiyecekler, yeni kredi politikaları, ülkedeki kalkınma havası, CHP'nin

\footnotetext{
39 Tevfik Çavdar, "Siyasal Gelişmenin Evreleri”, Cumhuriyet Dönemi Türkiye Ansiklopedisi, VIII, İstanbul, 1983, s.2025

${ }^{40}$ Haluk Ülman, "Seçim Sistemimiz Ve Başlıca Siyasi Partilerimiz" Ankara Üniversitesi Siyasal Bilgiler Fakültesi XXII, 1957.s.45

${ }^{41}$ Ülman, , "Seçim Sistemimiz Ve Başlıca Siyasi Partilerimiz"...s.48

${ }^{42}$ Bernard Lewis, Modern Türkiyenin Doğuşu Ankara 1991.s.302
} 
geçmişte hayata geçirdiği politikalara halkın duyduğu tepki geniş halk kitlelerini DP'ye yönlendirdi. ${ }^{43}$

14 Mayıs 1950 seçimlerinde 8.905.576 seçmenden 7.916.091's1 oy kullanmış olup katılım oranı $\% 88.88^{\prime} \mathrm{di}^{44}$ Milletvekillerinin oy oranı ve kazandığı milletvekilleri sayısı ise şu şekildeydi ${ }^{45}$.

$\begin{array}{llll}\text { Aldı } \breve{~} 1 & \text { Oy } & \text { Oran: } & \text { Milletvekili Sayıs1 } \\ \text { DP } & 4.242 .831 & \% 53.59 & 408 \\ \text { CHP } & 3.165 .096 & \% 38.98 & 69 \\ \text { MP } & 240.208 & \% 3.03 & 1 \\ \text { Bağımsız } & 267.959 & \% 3.40 & 9\end{array}$

Demokrat Parti seçimleri 45 ilde (Afyon, Ağrı, Amasya, Ankara, Aydın, Balıkesir, Bilecik, Bolu, Burdur, Bursa, Çanakkale, Çankırı, Çorum, Denizli, Diyarbakır, Edirne, Elazı̆̆g, Erzurum, Gaziantep, Giresun, Gümüşhane, Isparta, İçel, İstanbul, İzmir, Kayseri, Kırklareli, Kocaeli, Konya, Kütahya, Mânise, Maraş, Muğla, Niğde, Samsun, Seyhan, Sinop, Sinop, Siirt, Sivas, Tekirdağ, Tunceli, Urfa, Zonguldak) tam liste halinde kazand. DP Kastamonu'dan 5, Kırşehir ve Mardin'den 1'er, Ardahan'dan 2, Tokat'tan 8, Trabzon'dan 3 milletvekili çıkarmış. Hakkâri' den ${ }^{46}$ hiç oy alamamıştı. ${ }^{47}$

DP, feodal ilişkilerin geçerli olduğu, sosyal ve ekonomik yaşam düzeyinin düşük olduğu doğu illerinde seçimi kaybederken, bu illerde seçimi CHP kazand1. CHP, Bingöl, Bitlis, Erzincan, Hakkâri, Hatay, Kars, Malatya, Muş, Ordu, Sinop İllerinde tam liste halinde kazanarak 50 milletvekilini bu illerden çıkarmış, Kastamonu, Kırşehir, Mardin, Tokat ve Zonguldak'tan 1'er, Ordu'dan 6, Trabzon'dan 9 olmak üzere 71 milletvekili kazanmıștı. Ancak Zonguldak milletvekili Sebatı Ataman ve Yozgat Milletvekili Avni Doğan'ın seçim tutanaklarının iptal edilmesi nedeniyle CHP'nin üye sayısı

\footnotetext{
${ }^{43}$ H. Bayram Kaçmazoğlu, Demokrat Parti Dönemi Toplumsal Tartışmalar, İstanbul 1998, s.197

${ }^{44}$ Cumhuriyet 26 Mayıs 1950, Ayın Tarihi S.198(Mayıs 1950)s.13

${ }^{45}$ Cumhuriyet 26 Mayis 1950

${ }^{46}$ Hakkâri 1950 Milletvekili Seçimleri öncesinde DP ve CHP'den birer aday vardı. DP'den Alidayı Gazetesi sahibi ve baş muhabiri Mithat Eriş CHP'den ise VIII. Dönem Hakkari Milletvekili Selim Seven adaylıklarını açıklamışlardı. Seçim zamanı DP adayı seçimden çekilerek CHP adayı Selim Seven tek başına seçime katıldı. Hakkari'de 12. 384 kişinin oyunu alarak milletvekili seçildi. Ayrıntılı bilgi için bkz; Erol Tuncer, 1950 Seçimleri, Ankara, 2010,

${ }^{47}$ BCA, 030.10.77.511.11.1 Ayın Tarihi S.198, (May1s 1950)s.19
} 
69'a düștü. ${ }^{48}$ Millet partisinden ise yalnızca Osman Bölükbașı Kırșehir'den 28.034 oy alarak meclise girdi. ${ }^{49}$

Kars'da yapılan seçimlerde Yusuf Paşa Mahallesi'nden 1022, Ortakap1 Mahallesi'nden 1053, Sukap1 Mahallesi'nden 511, Bülbül Mahallesi'nden 367, Yeni Mahalle'den 1680, Bayrampaşa Mahallesi'nden 432, Kaleiçi Mahallesi'nden 1124, İstasyon Mahallesi'nden 1256, Ağadere köyü 143, Küçük Yusuf Köyü 157, Çerme Köyü'nden 155 ve Ala köyünden 170 kişi oy kulland. ${ }^{50} 14$ Mayıs 1950 tarihinde yapılan seçimde CHP, Kars'ta 10 milletvekilinin 10'unu da kazanarak büyük bir başarı sağladı. Seçimlerde Kars'a kayıtlı seçmen sayısı 156502'dir. Oy kullanan sayıs1 139749 katılım oran 1 ise \%89, 3 dür. ${ }^{51}$ Kars seçimlerinde CHP 76561 (\%58, 5), DP 54112 $(\% 41,3)$, Bağımsızlar ise $917(\% 0,2)$ oy ald..$^{52}$

Seçimde Fevzi Aktaş 78.814, Latif Aküzüm 76.067, Sırrı Atalay 79.155, Mehmet Bahadır 74.247, Abbas Çetin 74.250, Veis Koçulu 70.847, Esat Oktay 73.246, Tezer Taşkıran 83.411, Hüsamettin Tugaç 75.935, Hüseyin Cahit Yalçın 78.955 oy ald $1{ }^{53}$ Seçilen milletvekillerinden Fevzi Aktaş, Mehmet Bahadır, Esat Oktay, Tezer Taşkıran ve Hüsamettin Tugaç VIII. Dönemde Kars milletvekilliği görevini yürütmüş kişilerdi. Diğer beş milletvekili ise ilk kez Kars milletvekilliğine seçilmişlerdi. $\mathrm{Bu}$ milletvekillerinden

Latif Aküzüm: 1912 Kars Şöregel doğumludur. Baba adı Esadullah Turhan ana adı Tükezbandır. Ankara Hukuk Fakültesi mezunu Fransızca biliyordu. İstatistik Genel Müdürlüğü Muvakkat Tastık Memuru, Emniyet Genel Müdürlüğü 5, Sınıf Muamelat memuru, İktisat Bakanlığı Zonguldak Mintıka Müdürlügü memuru, Serbest Avukat görevlerinde bulundu. Evli ve dört çocuk babasıdır. 20 Kasım 1975 tarihinde vefat etti. CHP Kars milletvekilliğine seçildikten sonra bir süre bağımsız milletvekilliği görevinde bulundu.1953 yllında ise Demokrat Partiye geçti.

Sırrı Atalay:1919 Pasinler doğumlu. Baba adı Abbas ana adı Ayşe Ankara Hukuk Fakültesi mezunu İngilizce biliyordu. Savc1 ve hakimlik görevlerinde bulundu. Lice Cumhuriyet Savc1 Yardımcısı, Kiğ 1 Yargıç

\footnotetext{
${ }^{48}$ Zafer, 6-7 Haziran 1950, Ulus 9 Temmuz 1950

${ }^{49}$ Ayın Tarihi, S.198, Mayıs 1950, s.17

${ }^{50}$ Kars Gazetesi, 15 Nisan 1950, S.1821

${ }^{51}$ E. Tuncer, 1950 Seçimleri..., s.298

${ }^{52}$ E. Tuncer, 1950 Seçimleri... s.330

${ }^{53}$ Kars Gazetesi, 24 Mayıs 1950, S.1832, BCA, 030.10.77.511.11 Akşam, 16 Mayıs 1950
} 
Yardımcısı, Iğdır Yetkili Sorgu Yargıcı görevlerini yürüttü. Evli bir çocuk babasıydı 09 Eylül 1985 tarihinde öldü. ${ }^{54}$

Abbas Çetin (Abbasali) :1914 Revan doğumlu. Baba adı Abdulali ana adı Güzel Ankara Hukuk Fakültesi mezunu. Savcı ve hakimlik görevlerinde bulundu. Maliye Tahsil Müfettişliği, Ankara ve Kars Mahkemeler Katibi, Kağızman Hakim Yardımcısı, Kağızman Sorgu Hakimi, Kars Ceza Hakimi, Pötürge Yargıcı, Erzincan Cumhuriyet Savcı Yardımcısı, Diyarbakır Ağır Ceza Mahkemesi üyesi, Yozgat Sulh Yargicı, Serbest Avukat, Hazine Avukatı görevlerinde bulundu. Evli dört çocuk babası 26 Ağustos 1975 tarihinde öldü. CHP Kars Milletvekilliğine seçildikten sonra Bir süre bağımsız milletvekilliği görevinde bulundu.1953 yılında ise Demokrat Partiye geçti

Veyis Koçulu:1891 Tiflis doğumlu. Baba adı Molla Abbas ana adı Hürü, lise mezunu. Rusça biliyordu. Ticaret ve Tüccarlıkla uğraştı. Kars İl Genel Meclis üyesi olarak görev yaptı, evli yedi çocuk babasıydı. 17 Şubat 1984 tarihinde öldü. ${ }^{55}$. CHP Kars milletvekilliğine seçildikten sonra Bir süre bağımsız milletvekilliği görevinde bulundu.1953 yılında ise Demokrat Parti'ye geçti

Hüseyin Cahit Yalçın:1877 İstanbul doğumlu. Baba adı Ali Rıza, Ana adı Fatma Piza Mülkiye Mektebi mezunu. İngilizce İtalyanca ve Fransızca biliyordu. Siyasi ve İçtimai İlimler, Diplomasi ve İçtimaiyat, Edebiyat, Basın, Maarif Nezareti Mektebi Kalemi, Hulefası, Hulefa İdadisi Müdür Yardımcısı ve Kitabet Öğretmeni, Fransızca Öğretmeni, Mercan İdadisi Müdürü, Serveti Fünun Dergisi Yöneticisi, Tanin dergisi sahibi ve başyazarı, Duyunu Umumiye Osmanlı Deyinler Vekili, Sanayii ve Maadin Bankas1 İdare Meclisi Başkanı, Fikir Hareketleri dergisi sahibi, Akşam gazetesi ve Yenigün dergisi yazarı, Yeni Sabah Gazetesi, Ulus Gazetesi Başyazarı, Osmanlı Meclisi Mebusan I.II. ve III. dönem İstanbul Mebusu, II. Dönem Meclisi Mebusan Başkan Vekili, VI. dönem Çankırı, VII ve VIII dönem İstanbul milletvekilliği görevlerinde bulundu. Evli ve iki çocuk babasıydı. 18 Ekim 1957 tarihinde öldü. ${ }^{56}$

\section{2-1950 Kars Belediye Seçimleri}

3 Eylül 1950 tarihinde ülkede çekişmeli bir ortamda belediye seçimleri yapıldı. Yapılan seçimlerde katılım oranı ülke genelinde değişiklik arz

\footnotetext{
${ }^{54}$ T.B.M.M. Albümü II... s.572, Sırrı Atalay, Bir Ömür Politika... s.12-28

${ }^{55}$ T.B.M.M. Albümü II... s.572,

${ }^{56}$ T.B.M.M. Albümü II... s.572, Hüseyin Cahit Yalçın, Siyasi Anılar, Türkiye İş Bankası Yayınları, İstanbul, 1976,
} 
etmekle birlikte 600 belediyenin 560'nı Demokrat Parti adayları kazand1. ${ }^{57}$ Kars'ta da 1950 yılında belediye başkanlığı seçim çalışmaları başladı. 1580 ve 5669 sayılı belediye kanununa göre düzenlenen seçmen kütük listeleri askıya çıkarıldıktan sonra listeler açıklandı. Kars Belediyesi için oy verecekler Su Kapı Mahallesi, Demir Köprü Bakkal Settarın Dükkanı, Yusufpaşa Mahallesi Ziya Gökalp Okulu, İstasyon Mahallesi Gazi Muhtar Paşa Okulu, Kaleiçi Mahallesi Köprü başında Muhtar Nadirin Dükkanı, Bayrampaşa Mahallesi beden kenarı Bakkal Arslan Odyarın dükkanı, Bülbül Mahallesi köprü başında Ali Senger'in dükkanında, Orta Kapı Mahallesinde Fevzi paşa okulunda oylarını kullandı. 1580 sayılı belediye kanununa göre belediye başkanlığına aday olanlarda şu şartlar olmalıydı. Türk olmak, seçim başlamadan önce beldede ikamet ettiğini ispat etmek, 18 yaşını bitirmiş olmak, ağır hapis cezasına çarptırılmamış olmak, hırsızlık-dolandırıcılık, iflas gibi yüz kızartıcı suçlarla mahkum olmamak ve silah altında bulunmamak gibi özellikler aranmışt ${ }^{58}$

1950 genel seçimlerini DP büyük bir zaferle kazandıktan sonra 3 Eylül 1950 de gerçekleştirilen belediye seçimlerinde DP 875.355 oyla \%57,6, CHP 570.606 oy alarak \%37,5 oy, Millet partisi $58.131 \% 3,8$, bağımsızlar ise 50.971 oyla \%3,3 oranında oy almışlardı. Seçimler sonucunda belediye meclis üyeliklerde şu şekilde şekillenmişti. ${ }^{59}$

$$
\begin{array}{ll}
\text { Demokrat Parti- } 5900 \text { üyelik } & \% 60,5 \\
\text { Cumhuriyet Halk Partisi- } 3448 \text { üyelik } & \% 35,4 \\
\text { Millet Partisi - } 147 \text { üyelik } & \% 1,5 \\
\text { Bağımsız- } 250 \text { üyelik } & \% 2,6
\end{array}
$$

$\mathrm{Bu}$ sonuçlar genel seçimlerden sonra DP'nin seçim sonucunu perçinleştiren ikinci zaferi oldu. Seçim sonuçlarına göre DP 349, CHP 218, MP 6, Bağımsız ise 12 bölgeden belediye başkanı çıkardı $1{ }^{60}$ Kars'ta yapılan seçimler CHP ve DP'nin rekabetine sahne oldu. Kars'ta 22.053 seçmenden 15.439 'u oy kulland1, CHP 7768, DP ise 8117 oy ald1. ${ }^{61}$ DP'den Nevruz Gündoğdu belediye başkanlığına seçildi. Kars'ta DP'den belediye başkanı seçilen bir ilçesi de Posof'tu. Posof'ta da seçimleri DP kazandı. Fakat Sarıkamış, Çıldır ve diğer ilçelerde ise CHP adayları büyük çoğunlukla

\footnotetext{
${ }^{57}$ Mustafa Albayrak, Türk Siyasi Tarihinde Demokrat Parti, Ankara, 2004, s.200-201.

${ }^{58}$ Kars Gazetesi 12 Ağustos 1950, S.1856

${ }^{59} \mathrm{BCA}, 030.01 .51 .309 .4$

${ }^{60} \mathrm{BCA}, 030.01 .51 .309 .3$

${ }^{61} \mathrm{BCA}, 030.01 .51 .309 .3$
} 
seçimleri kazand1. ${ }^{62}$ Seçim sonuçları üzerine Başbakan Menderes "Türk Milleti Halk Partisini 14 Mayıs'ta iktidardan tasfiye etmişti; 3 Eylülde de muhalefetten tasfiye etti” diyerek seçim sonuçlarındaki mutluluğunu dile getirse de; Kars'ta anlaşılan o tasfiye gerçekleşmemiş, nispeten düşük katılımla gerçekleşen seçimler sonucunda DP sadece Kars merkez ve Posof ilçesindeki seçimleri kazanmıştı.

\section{Sonuç}

7 Ocak 1946 tarihinde CHP'den ayrilan bazı milletvekilleri Celal Bayar'ın önderliğinde birleşerek DP'yi kurdu. DP, 7 Ocak 1946 yılında tüm illerde örgütlenme çalışmalarına başladı. Her vilayetin kendine özgü şartları olmasından hareketle, Kars'ta DP'nin örgütlenmesi başlangıçta oldukça yavaştı. Sadece birkaç kazada bu yeni parti kendisine yaşam alanı bulabilecekti. Partinin üyeleri de CHP teşkilatlarından ayrılan kişilerdi. Bunların büyük bir kısmı da yönetimde yetki sahibi idi. Fakat ilerleyen süreçte DP, CHP ile şiddetli bir rekabete girdi. Doğal olarak burada sergilenen siyasi söylemin de yaşanılan tartışmalarda belirleyici rolü olacaktı. DP Genel Merkezi'nin CHP'ye yönelik eleştirileri Kars'ta da köylere kadar kendisini hissettirdi. Bunun karşısında CHP'nin takındığ 1 tavırda oldukça önemliydi.

Bütün bu gelişmeler DP'nin örgütsel sorunları ile eş zamanlı olarak yaşandı. Çünkü DP'de çözülmeler başladı. Bu da DP'nin Kars özelindeki durumundan kaynaklanmaktaydı. Bazı ilçelerde güçlüyken, bazılarında ise istenilen ölçüde varlık gösteremedi. Yaşanılan siyasi rekabet toplumsal değer yargılarının sınırlarını zorlayacak seviyedeydi. Bu durumun halk nezdindeki yansıması ise DP'nin aleyhine olacaktı. 1950-1960 arası Kars'ta hiçbir varlık gösteremeyecekti. Kars'ın kendine özgü yapısı da seçimleri etkileyen bir diğer etkendi. Çünkü 1921 itibariyle Kars ve çevresini terk eden Ermeniler, Rusya'ya yerleştiler. Böylece bu bölgeyi boşalttılar. Rusların ve Ermenilerin bu bölgeyi terk etmesinden sonra buraların sahipsiz kalmasını önlemek amaciyla boş olan yerlere Azerbaycan'dan Kars'a yerleşen Azeri Türkleri, Bolşevik cereyanının Kafkasya'da yayılması sırasında bu rejime karşı olan Karapapak Türkleri, dar arazili ve geçim sıkıntısı içinde yaşayan Karadenizliler ve Anadolu'nun çeşitli yerlerinden göçüp yerleşen Türkler yerleştirildi. Bu göçler, Kars'ta bir takım problemler yarattı. Yerli halk ile göçmen Türkler arasında ticari anlamda var olan rekabet ileriki yıllarda ŞiiSünni ayrılığına döndü. Bu etkiyi ve ayrımcılığı ortadan kaldırmak için partiler seçimlerde dengeli aday belirlemeye çalıştı. Bu amaçla CHP Azeri

\footnotetext{
${ }^{62}$ BCA, 030.01.51.309.3
} 
kökenli olan Abbas Çetin, Latif Aküzüm ve Azerbaycan doğumlu Ahmet Ağaoğlu'nun kızı Tezer Taşkıran'ı aday gösterdi.

$\mathrm{Bu}$ genel değerlendirmeler 1şı̆̆ında DP Kars'ta yeterince örgütlenemediği için 1946 Milletvekili Genel Seçimlerinden itibaren 1950'ye kadar yapılan diğer seçimlere katılamadı 1950 seçimlerinde DP gerek mahalli seçimlerde gerekse milletvekili seçimlerinde önemli bir başarı gösteremedi. Sadece mahalli seçimlerde Kars merkez ve Posof ilçesinde belediye başkanlıklarını kazandı.

\section{Kaynakça}

Akşam, 16 Mayıs 1950

Ayın Tarihi

$\mathrm{BCA}$,

Lewis, Bernart, Modern Türkiyenin Doğuşu Ankara 1991.

Cumhuriyet

Tuncer, Erol, 1950 Seçimleri, Ankara, 2010.

Barutçu, Faik Ahmet, Siyasi Anılar (1939-1954), İstanbul, 1998.

Kaçmazoğlu, H. Bayram, Demokrat Parti Dönemi Toplumsal Tartışmalar, İstanbul 1998

Ülman, Haluk, "Seçim Sistemimiz Ve Başlıca Siyasi Partilerimiz" Ankara Üniversitesi Siyasal Bilgiler Fakültesi XXII 1957.

Yalçın, Hüseyin Cahit, Siyasi Anılar, Türkiye İş Bankası Yayınları, İstanbul, 1976

Kars Gazetesi

Albayrak, Mustafa, Türk Siyasi Tarihinde Demokrat Parti, Ankara, 2004, s.200-201

Burçak, Rıfkı Salim, On Yılın Anıları, (1950-1960), Ankara, 1998.

Atalay, Sırrı, Bir Ömür Politika, Kars’tan Zincirbozan'a, Milliyet Yayınları İstanbul 1986.

TBMM. Albümü II

Çavdar, Tevfik, "Siyasal Gelişmenin Evreleri”, Cumhuriyet Dönemi Türkiye Ansiklopedisi, VIII, İstanbul, 1983.

Ulus

Zafer 